\title{
Fluorinated and Charged Hydrogenated Alkanethiolates Grafted on Gold: Expanding the Diversity of Mixed-Monolayer Nanoparticles for Biological Applications
}

\author{
Silvia Bidoggia, ${ }^{\dagger}$ Francesca Milocco, ${ }^{\dagger}$ Stefano Polizzi, ${ }^{\dagger}$ Patrizia Canton, ${ }^{\ddagger}{ }^{\dagger}$ Alessandra Saccani, ${ }^{\S}$
}

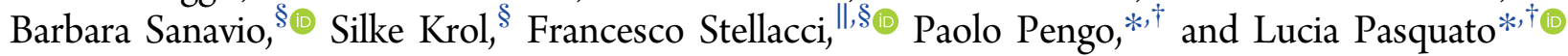

${ }^{\dagger}$ Department of Chemical and Pharmaceutical Sciences, University of Trieste and INSTM Trieste Unit, via L. Giorgieri 1, 34127 Trieste, Italy

${ }^{\ddagger}$ Dipartimento di Scienze Molecolari e Nanosistemi and Centro di Microscopia Elettronica R. Stevanato, Università Ca’ Foscari Venezia, Via Torino 155/b, 30172 Venezia-Mestre, Italy

${ }^{\S}$ NanoMed lab, Fondazione IRCCS, Istituto Neurologico “Carlo Besta”, IFOM-IEO-campus, via Adamello, 20133 Milan, Italy

"Institute of Materials, École Polytecnique Fédérale de Lausanne, Lausanne CH-1015, Switzerland

Supporting Information

\begin{abstract}
Low intrinsic toxicity, high solubility, and stability are important and necessary features of gold nanoparticles to be used in the biomedical field. In this context, charged nanoparticles proved to be very versatile, and among them charged mixed-monolayer gold nanoparticles, displaying monolayers with well-defined morphologies, represent a paradigm. By using mixtures of hydrogenated and fluorinated thiols, the formation of monolayer domains may be brought to an extreme because of the immiscibility of

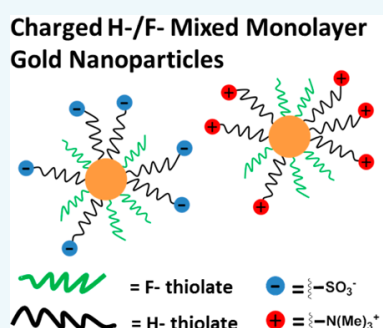
fluorinated and hydrogenated chains. Following this rationale, mixed monolayer gold nanoparticles featuring ammonium, sulfonate, or carboxylic groups on their surface were prepared by using amphiphilic hydrogenated thiols and $1 \mathrm{H}, 1 \mathrm{H}, 2 \mathrm{H}, 2 \mathrm{H}$-perfluoro-alkanethiols. The toxicity of these systems was assessed in HeLa cells and was found to be, in general, low even for the cationic nanoparticles which usually show a high cytotoxicity and is comparable to that of homoligand gold nanoparticles displaying amphiphilic-charge neutral-hydrogenated or fluorinated thiolates in their monolayer. These properties make the mixed ligand monolayer gold nanoparticles an interesting new candidate for medical application.
\end{abstract}

\section{INTRODUCTION}

The unique lipophobic and hydrophobic nature of fluorocompounds represents a tremendous, but so far little exploited, opportunity in the design of self-assembled materials. Indeed, the use of fluorinated (F-) subunits often yields species with very different structures and properties with respect to hydrogenated ( $\mathrm{H}-)$ analogues, offering a simple way to expand the diversity of systems for applications in the biomedical field. In this context, the extreme hydrophobicity of fluorocompounds may enable mechanisms of interaction with biologically relevant structures, such as cell membranes, that are different from those operative for hydrogenated systems. In addition, their stability, due to the strength of the $\mathrm{C}-\mathrm{F}$ bonds, and low toxicity may also allow developing safe devices with extended lifetimes in vivo. Several examples highlight the remarkable properties of nanosized fluorinated systems that hold promise to improve the efficacy of nanomedicine. For instance, decoration of gold nanoparticles (AuNPs) with short perfluoroether moieties ${ }^{1}$ allowed their spontaneous selfassembly-triggered by fluorophilic interactions-into hollow superstructures $^{2}$ in the absence of external templates. A similar behavior was never reported for nanoparticles (NPs) bearing solely polyether units in their outermost layer. These NPs vesicles could be loaded with the fluorescent dye rhodamine or with the anticancer drug doxorubicin; this payload could then be released by laser irradiation at $532 \mathrm{~nm},{ }^{3}$ presenting potential as drug delivery systems based on AuNPs. ${ }^{4,5}$ Soft NPs made of peptide nucleic acid (PNA) conjugated to perfluoroundecanoyl chains display a 3-fold higher cellular uptake by HeLa cells with respect to undecanoyl PNA. ${ }^{6}$ Soft NPs obtained by complexation of polyampholites with perfluorododecanoic acid were found to hinder the formation of amyloid fibrils, while hydrogenated analogues were not effective. ${ }^{7,8}$ Furthermore, in a thermodynamic analysis of water-soluble fluorinated AuNPs as putative drug delivery systems, we found that nanoparticles

Special Issue: Interfacing Inorganic Nanoparticles with Biology

Received: October 10, 2016

Revised: November 11, 2016

Published: November 16, 2016 
A

\section{Ligands for the preparation of mixed monolayer nanoparticles}

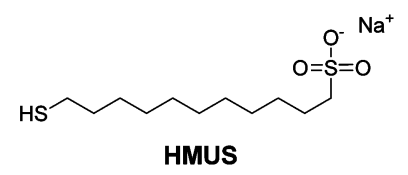

HMDDS

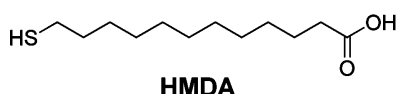

$\overbrace{\text { HMDA }}^{\mathrm{N}^{+-}} \mathrm{Cl}^{-}$

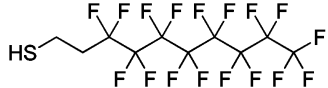

HF8

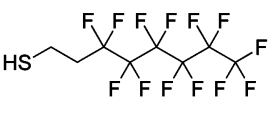

HF6
B

\section{Ligands for the preparation of homoligand nanoparticles}
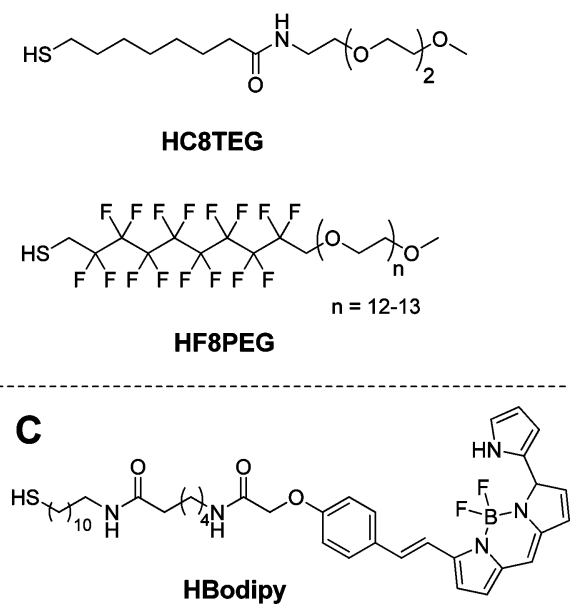

Figure 1. Thiols used in the preparation of charged H-/F-mixed-monolayer NPs, panel A; thiols used for the preparation of charge neutral homoligand AuNPs, panel B; and for NPs labeling, panel C.

displaying fluorinated ligands on their surface interact with drug-like guests with higher affinity than hydrogenated NPs of similar structure. ${ }^{9}$ Fluorinated soft NPs have been, indeed, proposed as drug delivery systems for doxorubicin. ${ }^{10,11}$ An additional feature of fluorinated materials, including AuNPs, is that they may be easily engineered into contrast agents for ${ }^{19} \mathrm{~F}$ magnetic resonance imaging, ${ }^{12,13}$ and by combining this application with drug delivery, novel theranostic platforms may become available. ${ }^{11}$ As far as monolayer protected AuNPs are concerned, the immiscibility of F- and H-thiolate ligands, arising from the lipophobicity of fluorocompounds, favors their self-sorting, with formation of domains, on the NPs surface. ${ }^{14-16}$ This finding is in keeping with what was observed in many examples of self-assembled systems comprising mixtures of hydrogenated and fluorinated components. For example, formation of phase segregated domains was indeed observed in the case of liposomes ${ }^{17}$ even when mixtures containing a mere $5 \%$ of fluorinated amphiphiles were used. The same behavior was also observed by AFM in a supported lipid bilayer of 1,2dipalmitoyl-sn-glycero-3-phosphocholine and of a semifluorinated analogue ${ }^{18}$ or in mixtures of arachidic and partially fluorinated carboxylic acids. ${ }^{19}$ On the other hand, studies on mixed hydrogenated/fluorinated self-assembled monolayers (SAMs) on flat surfaces are suggestive of less facile phase segregation. In particular, the adsorption on $\mathrm{Au}(111)$ of mixed disulfides featuring a hydrogenated chain and a fluorinated chain of different lengths - in a single disulfide moleculeresults in the formation of SAMs with no evidence of phase segregation. $^{20,21}$ Occurrence of phase segregation was not observed even after thermal annealing. ${ }^{22}$ Interestingly, coadsorption of a mixture of $\mathrm{H}$ - and F-thiols of the same length produces SAMs that are indistinguishable from the SAMs obtained by using the corresponding mixed disulfide. ${ }^{20}$ Instead, adsorption of blends of dissimilar $\mathrm{H}$ - and F-thiols results in the formation of small islands of the fluorinated ligands. ${ }^{23}$

The self-sorting of hydrogenated and fluorinated thiolates on curved surfaces may be the basis for the preparation of spontaneously patterned monolayers and provides a further approach to control the morphology of mixed monolayers in addition to those unraveled by the experimental and theoretical analyses of Stellacci $^{24,25}$ and Glotzer. ${ }^{26,27}$ In the context of nanoparticles-cell interaction, aside from the surface charge $^{28,29}$ and functionalization, ${ }^{30,31}$ the morphology of the coating monolayer is pivotal in determining the efficiency and the mechanism of the internalization process; ${ }^{32-34}$ the latter also being responsible for the toxicity of the NPs. ${ }^{35}$ This body of evidence comes from thorough analyses of mixed monolayer hydrogenated charged NPs of well-defined morphologies, ${ }^{32}$ while the effect of including F-ligands in the monolayer of these charged systems is, at present, completely unexplored. No information is also available on their toxicity in comparison to similar charged hydrogenated NPs. To start filling this gap, we then embarked in the synthesis of charged H-/F-mixedmonolayer AuNPs by using blends of thiols in which one of the components is a charged amphiphilic $\mathrm{H}$-thiol while the Fcomponent is selected among the readily available $1 \mathrm{H}, 1 \mathrm{H}, 2 \mathrm{H}, 2 \mathrm{H}$-perfluoro-alkanethiols. In particular, in order to favor the solubility in aqueous media the F-thiol length has to be shorter than that of $\mathrm{H}$-thiols but presenting at least six Fmethylene groups in order to exploit the lipophobicity properties for the monolayer organization. ${ }^{15}$ These NPs systems display good solubility in polar media, including water. Their toxicity and internalization pathway were preliminarily assessed on HeLa cells.

\section{RESULTS AND DISCUSSION}

For this study we prepared a series of H-/F-mixed monolayer AuNPs with different surface charges by using a mixture of ligands as reported in Figure 1A. The sodium salts of the 11mercaptoundecansulfonic acid (HMUS) and 12-mercaptododecanesulfonic acid (HMDDS) were used to provide NPs with permanent negative charges. The 12-mercaptododecanoic acid (HMDA) was used to provide the NPs with ionizable groups on the surface while 12-mercapto- $N, N, N$-trimethyl-1-dodecanaminium chloride (HTMDA) was designed in order to obtain NPs featuring permanent positive charges. These thiols were 
Table 1. Characterization Data for the Nanoparticles Used in This Study

\begin{tabular}{|c|c|c|c|c|c|c|}
\hline sample & initial $\mathrm{H}^{a}: \mathrm{F} 6$ & $x_{\text {in }}^{\mathrm{F}}$ & final $\mathrm{H}: \mathrm{F}^{b}$ & $x_{\text {fin }}^{\mathrm{F}}$ & diameter, ${ }^{c} \mathrm{~nm}$ & nanoparticles composition $^{d}$ \\
\hline NP-MDDS/F6-a & $1: 0.65$ & 0.40 & $5.0: 1$ & 0.17 & $3.3 \pm 0.5$ & $\mathrm{Au}_{1150}(\mathrm{MDDS})_{145}(\mathrm{~F} 6)_{29}$ \\
\hline NP-MDDS/F6-b & $1: 0.77$ & 0.44 & $2.5: 1$ & 0.29 & $3.2 \pm 0.7$ & $\mathrm{Au}_{1289}(\mathrm{MDDS})_{150}(\mathrm{~F} 6)_{60}$ \\
\hline NP-MDDS/F6-c & $1: 0.90$ & 0.47 & $1.5: 1$ & 0.40 & $3.4 \pm 0.7$ & $\mathrm{Au}_{1415}(\mathrm{MDDS})_{129}(\mathrm{~F} 6)_{87}$ \\
\hline NP-MDA/F6-a & $1: 0.65$ & 0.4 & $5.0: 1$ & 0.17 & $3.0 \pm 0.5$ & $\mathrm{Au}_{976}(\mathrm{MDA})_{136}(\mathrm{~F} 6)_{28}$ \\
\hline NP-MDA/F6-b & $1: 0.77$ & 0.44 & $2.9: 1$ & 0.26 & $2.5 \pm 0.6$ & $\mathrm{Au}_{523}(\mathrm{MDA})_{90}(\mathrm{~F} 6)_{30}$ \\
\hline NP-MDA/F6-c & $1: 1.30$ & 0.57 & $1.5: 1$ & 0.40 & $2.5 \pm 0.3$ & $\mathrm{Au}_{523}(\mathrm{MDDS})_{72}(\mathrm{~F} 6)_{49}$ \\
\hline NP-TMDA/F6-a & $1: 0.65$ & 0.40 & $5.0: 1$ & 0.17 & $3.9 \pm 0.9$ & $\mathrm{Au}_{2406}(\mathrm{TMDA})_{256}(\mathrm{~F} 6)_{51}$ \\
\hline NP-TMDA/F6-b & $1: 0.77$ & 0.43 & $1.1: 1$ & 0.48 & $4.2 \pm 0.7$ & $\mathrm{Au}_{2406}(\mathrm{TMDA})_{131}(\mathrm{~F} 6)_{119}$ \\
\hline NP-TMDA/F6-c & $1: 1.30$ & 0.57 & $1.3: 1$ & 0.43 & $4.0 \pm 0.9$ & $\mathrm{Au}_{2406}(\mathrm{TMDA})_{160}(\mathrm{~F} 6)_{124}$ \\
\hline
\end{tabular}

${ }^{a} \mathrm{H}$ stands for the hydrogenated ligand. ${ }^{b}$ Determined on decomposed NPs by ${ }^{1} \mathrm{H}$ NMR spectra analysis. ${ }^{c}$ Measured by TEM. ${ }^{d}$ Average NPs composition was calculated considering TEM and TGA data.

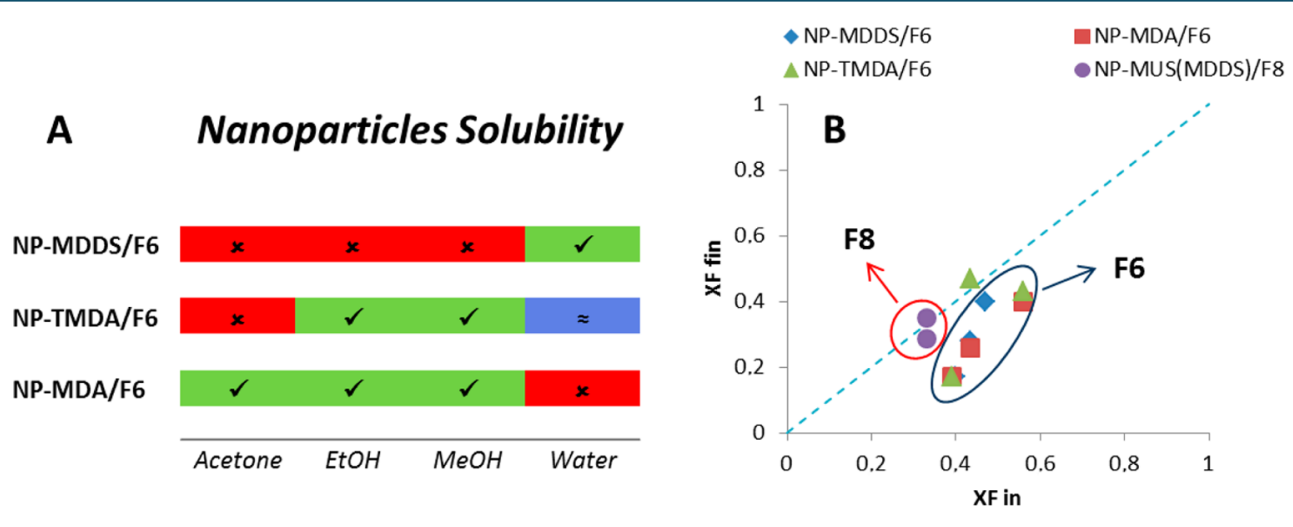

Figure 2. Panel A: synoptic view of the solubility properties of the H-/F-mixed monolayer NPs. Color code: red insoluble; green good solubility; indigo low solubility. Panel B: relationship between the initial composition of the reaction mixture and the final composition of the monolayer of the NPs expressed as the molar fraction of the F-ligand.

used in combination with $1 \mathrm{H}, 1 \mathrm{H}, 2 \mathrm{H}, 2 \mathrm{H}$-perfluoro-1-decanethiol (HF8) or $1 \mathrm{H}, 1 \mathrm{H}, 2 \mathrm{H}, 2 \mathrm{H}$-perfluoro-1-octanethiol (HF6) as the fluorinated components. The uptake by HeLa cells and the cytotoxicity of these charged H-/F-mixed monolayer AuNPs were compared to those of charge neutral NPs obtained by using the thiols $N-1-\{2-[2-(2$-methoxyethoxy)ethoxy] ethyl $\}-8$ sulfanyloctanamide (HC8TEG) and 2,2,3,3,4,4,5,5,6,6,7,7,8,8, 9,9-hexadecafluoro-10-(methoxy-PEG550) decan-1-thiol (HF8PEG), Figure 1B. The synthesis of the thiols HMDDS, HMDA, and HTMDA is reported in the Supporting Information (SI).

Nanoparticle Synthesis and Characterization. The development of anionic H-/F-mixed monolayer NPs was attempted at first by using the hydrophilic thiols HMUS or HMDDS blended to the highly hydrophobic thiol HF8 in a 2:1 molar ratio while the gold to thiol ratio was set to $1: 1$; the preparations were achieved by direct synthesis following the procedure reported by Stellacci and co-workers. ${ }^{36}$ The obtained nanoparticles NP-MUS/F8 ${ }^{37}$ and NP-MDDS/F8 were essentially insoluble in water. In seeking an improvement of the system solubility, the F-ligand in the blend was replaced by the shorter thiol HF6 and this was used in combination with HMDDS, in order to ensure a better masking of the fluorinated thiolate, and/or of the fluorinated domains, from the solvent. The initial gold to thiols ratio was set to 2:1, in keeping with the previous cases, while the HMDDS:HF6 ratio was set to 2:1.3 and the reducing agent was added dropwise over $15 \mathrm{~min}$. The nanoparticles NP-MDDS/F6-a thus obtained displayed an average core diameter of $3.3 \pm 0.5 \mathrm{~nm}$, while, interestingly, the molar ratio between the MDDS and F6 thiolates in the monolayer was close to $5: 1$, very different from the initial
HMDDS:HF6 ratio (Table 1), indicating that the introduction of thiolate F6 in the monolayer of nanoparticles NP-MDDS/ F6-a is a disfavored process. ${ }^{38,39}$

In contrast to NP-MUS/F8 and NP-MDDS/F8, nanoparticles NP-MDDS/F6-a were nicely soluble in water. In order to explore these types of NPs in more detail, different values of the HMDDS/HF6 ratios were tested. Nanoparticles NPMDDS/F6-b with a core diameter of $3.2 \pm 0.7 \mathrm{~nm}$ and a MDDS:F6 final molar ratio of 2.5:1 could be obtained by using an initial MDDS:F6 ratio of $1.3: 1$; hence, also in this case the introduction of the F6 thiolate in the monolayer of nanoparticles NP-MDDS/F6-b is disfavored. The nanoparticles NPMDDS/F6-c with an average gold core diameter of $3.4 \pm 0.7$ $\mathrm{nm}$ and a mixed monolayer with a MDDS:F6 molar ratio of 1.5:1 were obtained by using an initial HMDDS:HF6 ratio of 1:0.9. With increasing amounts of F-ligand in the blend used for the synthesis up to a HMDDS:HF6 ratio of 1:2, the NPs were only soluble in fluorinated solvents such as trifluorotoluene.

The preparation of the H-/F-mixed monolayer nanoparticles NP-MDA/F6-a, NP-MDA/F6-b, and NP-MDA/F6-c, featuring carboxylic groups on the surface was achieved by using blends of the ligands HMDA and HF6 of different composition while maintaining constant the gold to total thiol molar ratio. The nanoparticles were obtained by direct synthesis using ethanol as solvent and a dropwise addition of the reducing agent over 15 min. The relevant synthetic and characterization data are reported in Table 1 .

Also with HMDA as hydrophilic ligand, the molar fraction of the F-ligand in the self-assembled monolayer on the gold surface was lower than that used for the synthesis. All of these systems display good solubility in alcohols but are sparingly 
soluble in water. The average size of the gold core for the nanoparticles NP-MDA/F6 is similar to those of NPs obtained by using the MDDS/F6 blends (Table 1 ).

The preparation of $\mathrm{H}$-/F-mixed monolayer NPs featuring a cationic surface was accomplished by using positively charged HTMDA in combination with HF6. As in the preceding examples, the preparation of the NPs was carried out by direct synthesis using a gold to thiols ratio of $3: 2$, while the HTMDA/ HF6 ratio used was set to 1:0.65 for NP-TMDA/F6-a, 1:0.77 for NP-TMDA/F6-b, and 1:1.3 for NP-TMDA/F6-c, and their characterization data are reported in Table 1. Also in this case, the introduction of the HF6 ligand in the monolayer of the NPs was found to be disfavored nicely matching the trend observed for the negatively charged and charge neutral nanoparticles NPMDDS/F6 and NP-MDA/F6, respectively. However, the size of the NPs core is slightly larger (see Table 1) than that obtained by using blends of thiols HMDDS/HF6 and HMDA/ F6; the standard deviation of the core size is also larger. All nanoparticles NP-TMDA/F6 are soluble in methanol and ethanol and slightly soluble in water or basic buffers.

The introduction of polar end groups in the $\mathrm{H}$-thiolates of nanoparticles NP-MDDS/F6, NP-MDA/F6, and NP-TMDA/ F6 allows for the first time a solubility in water which was not observed for mixed-ligand coated NPs featuring nonfunctionalized fluorinated thiolates. ${ }^{15,38}$

A synoptic view of the solubility properties of NP-MDDS/ F6-b, NP-MDA/F6-c, and NP-TMDA/F6-c is presented in Figure $2 \mathrm{~A}$. The relation between the composition of the $\mathrm{H}$ - and F-ligands used in the NPs synthesis and the composition of the resulting mixed monolayer can be conveniently analyzed by plotting the final molar fraction of the F-component in the monolayer against the molar fraction of the fluorinated ligand in the reaction mixture (Figure 2B). By using thiol HF8, the final monolayer composition closely matches the initial composition of the reaction mixture, while for NPs preparations where thiol HF6 was employed, the fraction of fluorinated thiolate was lower than its initial value. This is likely due to the combination of the lower number of fluorophilic interactions established between F6 chains and their shorter length with respect to F8 chains. A similar effect was observed in the preparation of several mixed monolayer NPs protected by blends of unfunctionalized hydrogenated thiolates and $1 \mathrm{H}, 1 \mathrm{H}, 2 \mathrm{H}, 2 \mathrm{H}$-perfluoro-alkanethiolates. ${ }^{38}$

Given the appreciable solubility of the nanoparticles NPMDDS/F6 and NP-TMDA/F6 in aqueous media, these systems were used for cell uptake and cytotoxicity studies. For comparison purposes, homoligand-charge neutralAuNPs NP-C8TEG and NP-F8PEG were prepared by using the ligands HC8TEG and HF8PEG (Figure 1B), according to procedures already reported by our group. ${ }^{40,41}$

Tagging of Gold Nanoparticles with Fluorescent Labels. Nanoparticles NP-MDDS/F6-b, NP-TMDA/F6-c, NP-C8TEG, and NP-F8PEG were labeled with a fluorescent ligand in order to monitor the internalization process by confocal fluorescence microscopy and cytofluorimetric analyses. For labeling we used the Bodipy functionalized thiol HBodipy ${ }^{13}$ (Figure 1C), obtaining the nanoparticles NP-C8TEG/Bodipy, NP-F8PEG/Bodipy, NP-MDDS/F6/Bodipy, and NP-TMDA/ F6/Bodipy (Table 2). The fluorescent units were introduced in the monolayer of the NPs by place exchange, the NPs were dissolved in water or methanol, and the appropriate amount of the HBodipy was added as a $1.95 \mathrm{mM}$ solution in a water/DMF 4:1 mixture. The place exchange reaction was performed for 3
Table 2. Characterization Data of the Bodipy Labeled Nanoparticles

\begin{tabular}{lcl}
\multicolumn{1}{c}{ BOmple } & BODY units per & \\
NP-F8PEG/Bodipy & 6 & nanoparticle composition \\
NP-C8TEG/Bodipy & 2 & $\mathrm{Au}_{976}(\mathrm{~F} 8 \mathrm{PEG})_{114}(\mathrm{BODIPY})_{6}$ \\
NP-MDDS/F6/ & 6 & $\mathrm{Au}_{760}(\mathrm{C} 8 \mathrm{TEG})_{168}(\mathrm{BODIPY})_{2}$ \\
Bodipy & & $\mathrm{Au}_{1289}(\mathrm{MDDS} /$ \\
NP-TMDA/F6/ & 5 & $\mathrm{~F} 6)_{204}(\mathrm{BODIPY})_{6}$ \\
Bodipy & & $\mathrm{Au}_{2406}(\mathrm{TMDA} /$ \\
& & $\mathrm{F} 6)_{279}(\mathrm{BODIPY})_{5}$ \\
\hline
\end{tabular}

days at $28{ }^{\circ} \mathrm{C}$. The degree of substitution was established by decomposing the NPs and assessing the amount of dye in solution by means of UV-vis spectroscopy and the resulting compositions are reported in Table 2.

For all NPs the amount of fluorescent dye introduced in the ligand shell was kept lower than 10 units per nanoparticle to avoid increasing the hydrophobicity of the NPs' surface and, in general, modifying the features of the monolayer.

Nanoparticle Interaction with HeLa Cells. The uptake of charged H-/F-mixed monolayer coated nanoparticles NPMDDS/F6/Bodipy and NP-TMDA/F6/Bodipy by HeLa cells was assessed by FACS analysis and fluorescence confocal microscopy imaging and compared to the uptake of the charge neutral homoligand nanoparticles NP-C8TEG/Bodipy and NPF8PEG/Bodipy. Prior to study the interaction with HeLa cells, the presence of free dye or free dye-labeled thiol HBodipy in the NPs preparations was tested by the red blood cells (RBCs) assay ${ }^{42}$ and no free dye could be detected (see Figure S22 and Figure S23). For the internalization studies the HeLa cells were plated at $3 \times 10^{5}$ cells $/ \mathrm{mL}$ in complete medium (with serum) and allowed to grow overnight. The cells were incubated with Bodipy labeled NPs at the concentrations of $0.05,0.1$, and 0.2 $\mathrm{mg} / \mathrm{mL}$ for $3.5 \mathrm{~h}$ at $37^{\circ} \mathrm{C}$ and imaged live by confocal laser scanning microscopy (CLSM). Cellular internalization of the Bodipy labeled NPs is shown by red fluorescence; the nucleus (in blue) was stained with Hoechst 33342. For all samples, cellular uptake is clear from confocal images with intense fluorescence signal in the cytosol and absence in the nucleus.

At $37{ }^{\circ} \mathrm{C}$, both the negatively and positively charged nanoparticles NP-MDDS/F6/Bodipy and NP-TMDA/F6/ Bodipy were internalized (Figure $3 \mathrm{~A}, \mathrm{~B}$ ), with a higher uptake in the case of the positively charged NPs. At $4{ }^{\circ} \mathrm{C}$, a temperature at which the endocytic and pinocytic uptake pathways are inhibited, no fluorescence could be observed in the cytoplasm of HeLa cells treated with NP-MDDS/F6/ Bodipy (Figure 3C), while in the case of NP-TMDA/F6/ Bodipy, the cell cytoplasm displayed a significant red fluorescence (Figure 3D). This is clear indication that the negatively charged particles are mainly internalized by an active energy dependent pathway while the positive particles are able to enter through the membrane into the cytosol of the cell.

A similar effect has been reported for other cationic NPs, ${ }^{43,44}$ and in silico analyses of the process ${ }^{45,46}$ explain it by NP entry through nanosized holes in the plasma membrane usually connected to significant cytotoxicity.

Accordingly, the cytotoxicity of the tested nanoparticles was determined by FACS analyses (Figure 4). For this, HeLa cells were incubated with NPs for $3.5 \mathrm{~h}$ at the concentrations of 0.05 , 0.1 , and $0.2 \mathrm{mg} / \mathrm{mL}$. Then the nonmembrane permeable fluorescent DNA-binding propidium iodide (PI) was used to determine cell membrane integrity. 

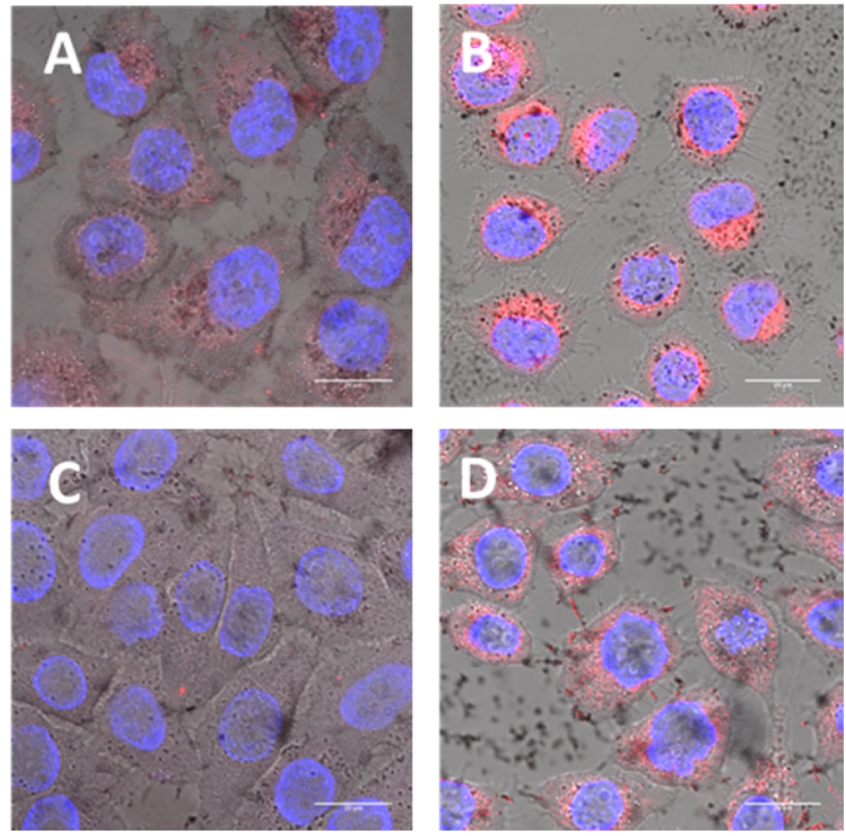

Figure 3. Confocal fluorescence micrographs merged with light microscopy images of HeLa cells incubated for $3.5 \mathrm{~h}$ at $37^{\circ} \mathrm{C}$ at a concentration of $0.1 \mathrm{mg} / \mathrm{mL}$ with NP-MDDS/F6/Bodipy (panel A), scale bar: $20 \mu \mathrm{m}$. Panel B: NP-TMDA/F6/Bodipy, scale bar: $20 \mu \mathrm{m}$. Confocal fluorescence micrographs merged with light microscopy images of HeLa cells incubated for $3.5 \mathrm{~h}$ at $4{ }^{\circ} \mathrm{C}$ at a concentration of $0.1 \mathrm{mg} / \mathrm{mL}$ with NP-MDDS/F6/Bodipy (panel C), scale bar: $20 \mu \mathrm{m}$. Panel D: NP-TMDA/F6/Bodipy, scale bar: $20 \mu \mathrm{m}$. The nucleus in all experiments was stained by Hoechst 33342 (blue).
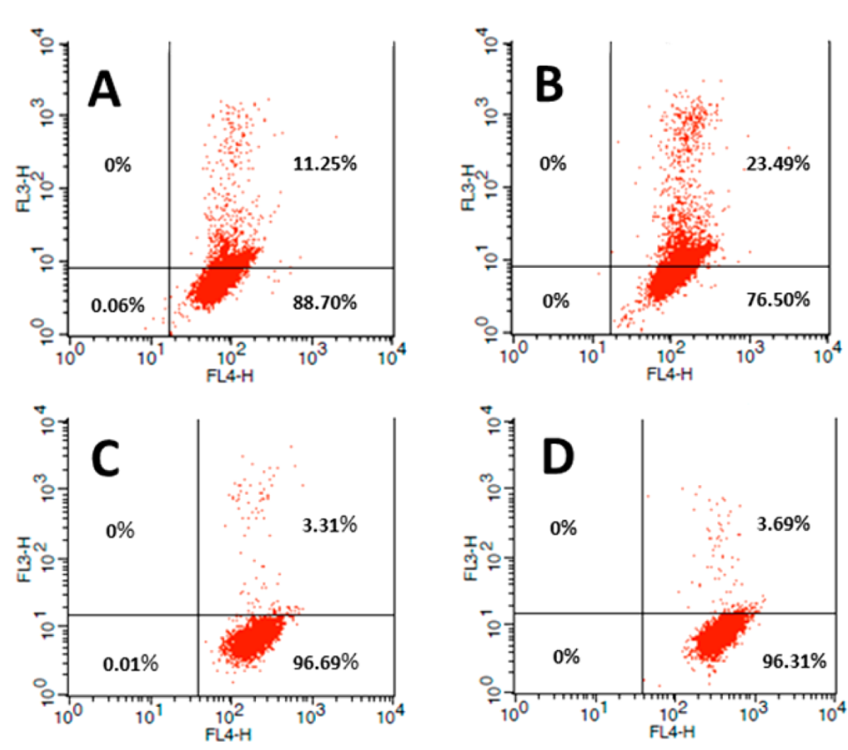

Figure 4. FACS analysis of HeLa cells incubated for $3.5 \mathrm{~h}$ at $37{ }^{\circ} \mathrm{C}$ with NP-MDDS/F6/Bodipy at a concentration of $0.05 \mathrm{mg} / \mathrm{mL}$ (panel A) and $0.1 \mathrm{mg} / \mathrm{mL}$ (panel B), or with NP-TMDA/F6/Bodipy at a concentration of $0.05 \mathrm{mg} / \mathrm{mL}$ (panel C) and $0.1 \mathrm{mg} / \mathrm{mL}$ (panel D).

We observed that the negatively charged NP-MDDS/F6/ Bodipy showed limited cytotoxicity to moderate toxicity in a concentration dependent manner with $38 \%$ of the cell population labeled with both NPs and PI indicating disruption of the cell membrane at a concentration of $0.2 \mathrm{mg} / \mathrm{mL}$ (Figure S24). In an assessment of NPs toxicity toward mammalian cells, Rotello and co-workers ${ }^{47}$ reported that anionic NPs, featuring, for instance, carboxylate groups on their surface, are less toxic than cationic NPs, with the anionic displaying $\mathrm{LC}_{50}$ values about 1 order of magnitude higher than the cationic. Surprisingly, we found that the positively charged NPTMDA/F6/Bodipy showed at maximum $7 \%$ of PI positive cells after exposure to the highest tested NPs concentration of $0.2 \mathrm{mg} / \mathrm{mL}$ (Figure S25). These percentages are comparable to those measured for untreated control cells. The limited toxicity of NP-TMDA/F6/Bodipy may imply that these cationic nanoparticles, at the concentrations tested, do not exert extensive damage to the plasma membrane upon internalization. For similar cationic hydrogenated nanoparticles, Rotello and co-workers reported a $\mathrm{LC}_{50}$ of about $1 \mu \mathrm{M}$; in the case of NP-TMDA/F6/Bodipy the highest concentration tested for which we could not observe cytotoxic effects was 0.2 $\mathrm{mg} / \mathrm{mL}$, corresponding to $0.35 \mu \mathrm{M}$, that is significantly lower than the $\mathrm{LC}_{50}$ value reported. It is thus intriguing that the anionic NP-MDDS/F6/Bodipy, instead, exert a significantly higher toxic effect than NP-TMDA/F6/Bodipy when tested at similar concentration levels. However, a recent thorough investigation of nanoparticle toxicities, by Stellacci and Pompa, ${ }^{35}$ on six cell lines, including HeLa cells, displays that nanoparticles presenting sulfonate groups on their surface and whose monolayer featured stripe-like domains remain essentially noncytotoxic at the same concentration at which nonstructured anionic nanoparticles exert a cytotoxic effect. It is not unlikely that in the case of NP-MDDS/F6/Bodipy the toxic effects observed are due to the organization of the monolayer. This hypothesis is also corroborated by the absence of internalization at $4{ }^{\circ} \mathrm{C}$ for nanoparticles NP-MDDS/F6/ Bodipy which might be expected if these nanoparticles present a stripe-like organization of the monolayer in analogy to similar mixed monolayer nanoparticles. ${ }^{24}$

The charge neutral nanoparticles NP-C8TEG/Bodipy and NP-F8PEG/Bodipy were also efficiently internalized at $37{ }^{\circ} \mathrm{C}$, as evidenced by the strong intensity of the red fluorescence in Figure 5A and Figure 6A, respectively. By performing the same experiments at $4{ }^{\circ} \mathrm{C}$, cellular uptake of NP-C8TEG/Bodipy or NP-F8PEG/Bodipy (Figure 5B and Figure 6B, respectively) was inhibited.

Cytofluorimetric analyses for NP-C8TEG/Bodipy showed no significant cytotoxicity; for all concentrations tested, more than $90 \%$ of the cells were viable after incubation with 0.05 and $0.1 \mathrm{mg} / \mathrm{mL}$ of the NPs for $3.5 \mathrm{~h}$ (Figure 5C and Figure 5D, respectively).

At the higher concentration of $0.2 \mathrm{mg} / \mathrm{mL}$ (Figure S26), the percentage of dead cells remains fairly constant and close to that measured in control experiments with untreated cells.

Nanoparticles NP-F8PEG/Bodipy gave similar results up to the concentration of 0.05 and $0.1 \mathrm{mg} / \mathrm{mL}$ (Figure 6C,D, respectively), while at the higher concentration tested, some cytotoxicity could be observed. Indeed, after exposure to 0.2 $\mathrm{mg} / \mathrm{mL}$ of NP-F8PEG/Bodipy the percentage of PI stained cells containing NPs was $16 \%$ (Figure S27). These data are in line with the toxicity of other homoligand PEG decorated fluorinated NPs. ${ }^{13}$

\section{CONCLUSIONS}

In this proof-of-principle study the preparation of a series of mixed H-/F-mixed monolayer AuNPs featuring cationic and anionic surfaces was achieved by direct synthesis using blends of simple hydrogenated thiols with charged end groups and commercially available $1 \mathrm{H}, 1 \mathrm{H}, 2 \mathrm{H}, 2 \mathrm{H}$-perfluoro-alkanethiols. 

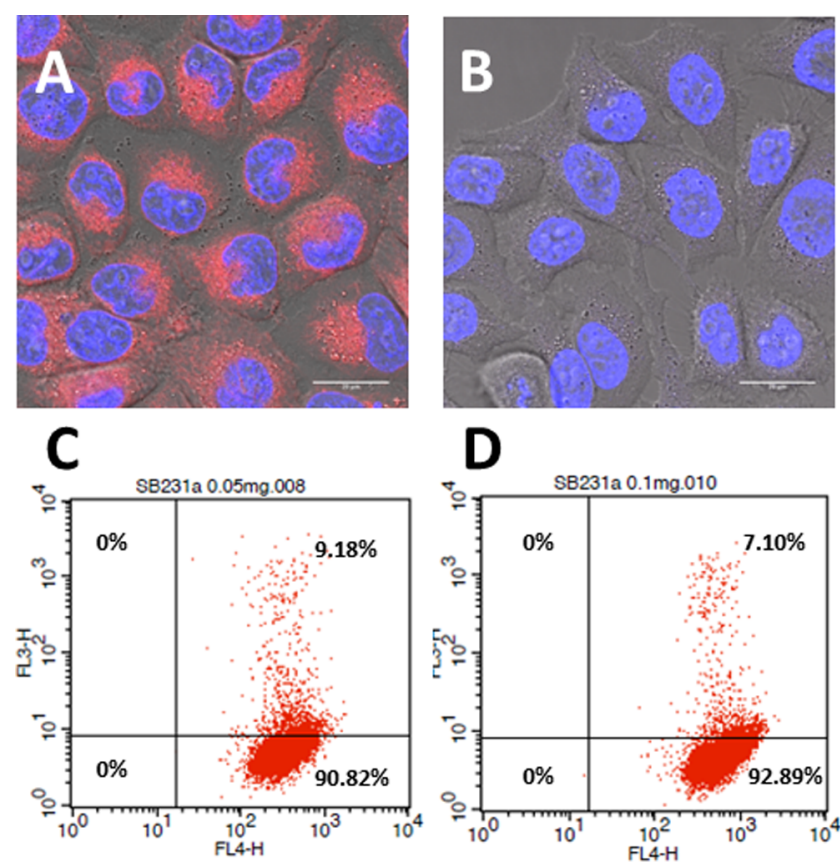

D

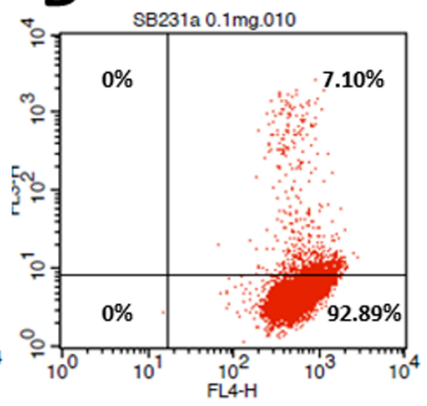

Figure 5. Merged light microscopy and confocal fluorescence images of HeLa cells incubated at a concentration of $0.1 \mathrm{mg} / \mathrm{mL}$ for $3.5 \mathrm{~h}$ with NP-C8TEG/Bodipy at $37{ }^{\circ} \mathrm{C}$ (A) NP-C8TEG/Bodipy or at $4{ }^{\circ} \mathrm{C}$ (B); scale bars: $20 \mu \mathrm{m}$. FACS analysis of HeLa cells incubated for $3.5 \mathrm{~h}$ with NP-C8TEG/Bodipy at a concentration of $0.05 \mathrm{mg} / \mathrm{mL}$ (C) or 0.1 $\mathrm{mg} / \mathrm{mL}(\mathrm{D})$.
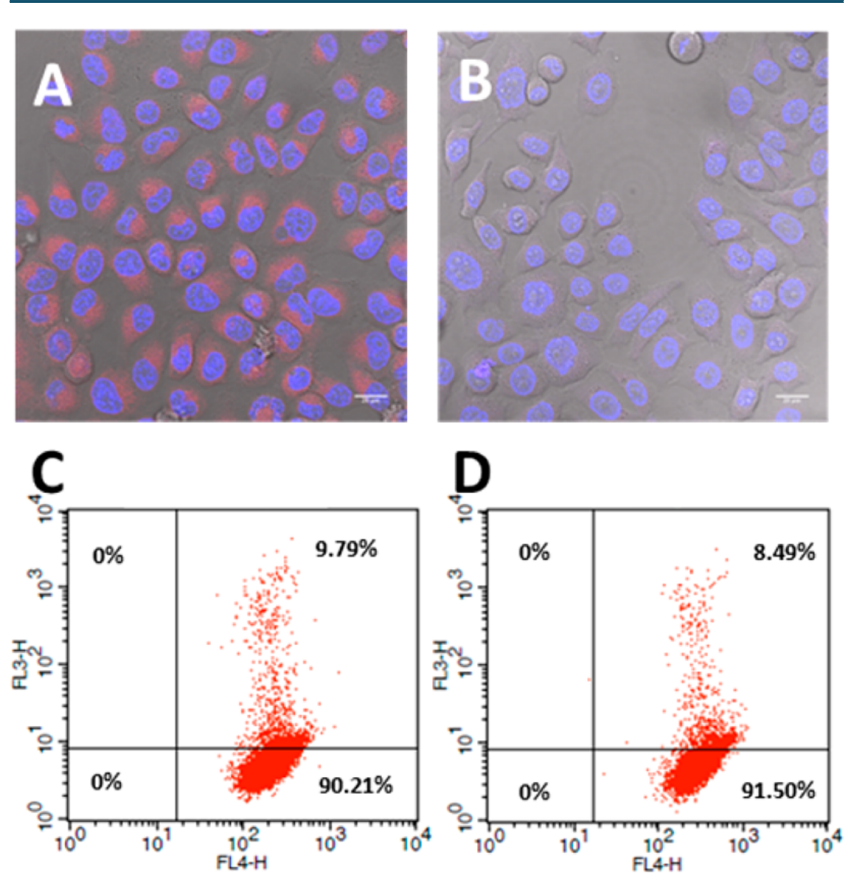

Figure 6. Merged light microscopy and confocal fluorescence images of HeLa cells incubated at a concentration of $0.1 \mathrm{mg} / \mathrm{mL}$ for $3.5 \mathrm{~h}$ with NP-F8PEG/Bodipy at $37{ }^{\circ} \mathrm{C}$ (A) or at $4{ }^{\circ} \mathrm{C}$ (B); scale bars: $20 \mu \mathrm{m}$. FACS analysis of HeLa cells incubated for $3.5 \mathrm{~h}$ with NP-F8PEG/ Bodipy at a concentration of $0.05 \mathrm{mg} / \mathrm{mL}$ (C) or $0.1 \mathrm{mg} / \mathrm{mL}$ (D).

The exploration of the ligand structure highlights that the length of the fluorinated thiol or, most likely, the difference in length between the hydrogenated and fluorinated ligands is a critical parameter to be considered for obtaining NPs with acceptable solubility properties. The fluorinated thiol has to be short enough, compared to the hydrogenated ligand, to form fluorinated domains that are sufficiently small to be masked from the solvent. In the present study we explored this aspect and found that the thiol HF8 is too long, producing NPs that are poorly soluble; on the contrary, the use of the two $\mathrm{CF}_{2}$ units shorter HF6 gave NPs with improved solubility. By this approach we achieved a tremendous broadening of the solvent spectrum in which H-/F-mixed monolayer NPs can be studied, including acetone, alcohols, and, most notably, water. At variance with previous examples, the systems presented here carry specific charged moieties paving the way to applications and studies thus far out of reach. The solubility in aqueous media of anionic NP-MDDS/F6 and cationic NP-TMDA/F6 nanoparticles, though not yet optimal, allowed us to perform some preliminary uptake and cytotoxicity studies toward HeLa cells. Both charged nanoparticle systems were readily internalized, but in uptake studies performed at $4{ }^{\circ} \mathrm{C}$, only NP-TMDA/F6 were found to enter the cells, suggesting that different internalization pathways are available to the different NPs. Nanoparticles NP-TMDA/F6 displayed only a limited toxicity and were well tolerated by the cells up to a concentration of $0.2 \mathrm{mg} / \mathrm{mL}$ indicating that, despite the cationic nature of this system, at this concentration there is little perturbation of the cell membrane. Instead, nanoparticles NP-MDDS/F6 displayed some cytotoxicity when tested at the same concentration. The charge neutral homoligand nanoparticles NP-C8TEG and NP-F8PEG were also tested for their cytotoxicity, and while the former were found to be nontoxic at all the concentration tested, the latter displayed some cytotoxicity when used at a concentration of $0.2 \mathrm{mg} / \mathrm{mL}$. Overall, the cationic nanoparticles NP-TMDA/F6 display toxicity similar to that of the charge neutral NPs. Given the well-established tendency of fluorinated thiolates to self-sort on the surface of AuNPs and the now available synthetic strategies to charged H-/F-mixed monolayer AuNPs we are confident that these systems, after further structural refinement, will significantly widen the span of NP systems with anisotropic monolayers to probe the interactions of nanosized matter with the biological environment.

\section{EXPERIMENTAL PROCEDURES}

Synthesis of NP-MDDS/F6-a. A $250 \mathrm{~mL}$ three-neck round-bottom flask was charged with $88.8 \mathrm{mg}\left(2.29 \times 10^{-4}\right.$ mol, 1 equiv) of $\mathrm{HAuCl}_{4} \cdot 3 \mathrm{H}_{2} \mathrm{O}$ dissolved in $50 \mathrm{~mL}$ of deoxygenated ethanol and $1.52 \times 10^{-4} \mathrm{~mol}(0.66$ equiv) of the thiol mixture (HF6:HMDDS $=0.65: 1)$. Then a $0.11 \mathrm{M}$ solution of $\mathrm{NaBH}_{4}$ in deoxygenated ethanol $\left(2.59 \times 10^{-3}\right.$ mol, 11.3 equiv) was added dropwise over $15 \mathrm{~min}$. The solution becomes brown-reddish and some precipitation of NPs was observed. The mixture was stirred for $3 \mathrm{~h}$ at room temperature, and afterward, the reaction vessel was kept at $4{ }^{\circ} \mathrm{C}$ overnight; the precipitated NPs were collected and the solvent was discarded. The NPs were washed with ethanol, methanol, and acetone and dried under vacuum. To completely remove unbound ligands, particles were dialyzed against $1 \mathrm{~L}$ of Milli-Q water for a total time span of $72 \mathrm{~h}$; the system was recharged with fresh water every $8 \mathrm{~h}$. The NP solution was collected and the solvent was removed under vacuum at a temperature lower than $45{ }^{\circ} \mathrm{C}$ obtaining the NPs as a red solid. The final ratio MDDS:F6 was 5:1. Solubility properties: Good solubility in water; not soluble in ethanol, methanol, and acetone. UV-vis (water) $\lambda_{\max }(\mathrm{nm})$ : Weak surface plasmon band at $508 \mathrm{~nm} .{ }^{1} \mathrm{H}$ NMR $(500 \mathrm{MHz}$, $\mathrm{D}_{2} \mathrm{O}$ ): $\delta=0.9-1.60$ (br, $\mathrm{CH}_{2}$ ), 1.77 (br, $\mathrm{CH}_{2} \mathrm{CH}_{2} \mathrm{SH}$ and 
$\mathrm{CH}_{2} \mathrm{CH}_{2} \mathrm{SO}_{3} \mathrm{Na}$ ), 2.88 (br, $\mathrm{CH}_{2} \mathrm{SO}_{3} \mathrm{Na}$ ). TEM: $X_{\mathrm{m}}=3.1 \mathrm{~nm} ; \sigma$ $=0.8 \mathrm{~nm} ; n=134$. TG Analysis: $19.5 \%$. Average composition: $\mathrm{Au}_{1150}(\mathrm{MDDS})_{145}(\mathrm{~F} 6)_{29}$.

Synthesis of NP-MDDS/F6-b. A $250 \mathrm{~mL}$ round-bottom flask was charged with $100 \mathrm{mg}\left(2.54 \times 10^{-4} \mathrm{~mol}, 1\right.$ equiv $)$ of $\mathrm{HAuCl}_{4} \cdot 3 \mathrm{H}_{2} \mathrm{O}$ dissolved in $56 \mathrm{~mL}$ of deoxygenated ethanol and $1.69 \times 10^{-4} \mathrm{~mol}$ (0.66 equiv) of the thiols mixture (HF6:HMDDS $=0.77: 1$ ). Then, a $0.11 \mathrm{M}$ solution of $\mathrm{NaBH}_{4}$ in deoxygenated ethanol $\left(2.87 \times 10^{-3} \mathrm{~mol}, 11.3\right.$ equiv $)$ was added dropwise over $17 \mathrm{~min}$. The solution becomes brownreddish and some precipitation of NPs was observed. The mixture was stirred for $3 \mathrm{~h}$ at room temperature and afterward the reaction vessel was kept at $4{ }^{\circ} \mathrm{C}$ overnight; the precipitated NPs were collected, and the solvent was discarded. The NPs were washed with ethanol, methanol, and acetone and dried under vacuum. The NPs were dialyzed against $1 \mathrm{~L}$ of Milli-Q water for $72 \mathrm{~h}$, recharging the system with fresh water every $8 \mathrm{~h}$. The NP solution was collected and the solvent was removed under reduced pressure working at temperature below $45{ }^{\circ} \mathrm{C}$. The residue was washed several times with hot ethanol to remove unbound thiols. The final ratio MDDS:F6 was 2.5:1. Solubility properties: Good solubility in water; not soluble in ethanol, methanol, and acetone. UV-vis (water) $\lambda_{\max }(\mathrm{nm})$ : Weak surface plasmon band at $508 \mathrm{~nm} .{ }^{1} \mathrm{H}$ NMR $(500 \mathrm{MHz}$, $\mathrm{D}_{2} \mathrm{O}$ ): $\delta=0.9-1.60$ (br, $\left.\mathrm{CH}_{2}\right), 1.77$ (br, $\mathrm{CH}_{2} \mathrm{CH}_{2} \mathrm{SH}$ and $\mathrm{CH}_{2} \mathrm{CH}_{2} \mathrm{SO}_{3} \mathrm{Na}$ ), 2.88 (br, $\mathrm{CH}_{2} \mathrm{SO}_{3} \mathrm{Na}$ ). TEM: $X_{\mathrm{m}}=3.2 \mathrm{~nm} ; \sigma$ $=0.7 \mathrm{~nm} ; n=253$. TG Analysis: $21 \%$. Average composition: $\mathrm{Au}_{1289}(\mathrm{MDDS})_{150}(\mathrm{~F} 6)_{60}$.

Synthesis of NP-MDDS/F6-C. A $250 \mathrm{~mL}$ round-bottom flask was charged with $97.3 \mathrm{mg}\left(2.47 \times 10^{-4} \mathrm{~mol}, 1\right.$ equiv $)$ of $\mathrm{HAuCl}_{4} \cdot 3 \mathrm{H}_{2} \mathrm{O}$ dissolved in $55 \mathrm{~mL}$ of deoxygenated ethanol and $1.65 \times 10^{-4} \mathrm{~mol}$ (0.66 equiv) of the thiol mixture $($ HF6:HMDDS $=1: 1.1)$. Then, a $0.11 \mathrm{M}$ solution of $\mathrm{NaBH}_{4}$ in deoxygenated ethanol $\left(2.80 \times 10^{-3} \mathrm{~mol}, 11.3\right.$ equiv $)$ was added dropwise over $12 \mathrm{~min}$. The solution becomes brownreddish observing some precipitation of NPs. The mixture was stirred for $3 \mathrm{~h}$ at room temperature and afterward the reaction vessel was then kept at $4{ }^{\circ} \mathrm{C}$ overnight; the precipitated NPs were collected and the solvent was discarded. The NPs were washed with ethanol, methanol, and acetone and dried under vacuum. The NPs were taken up with water and dialyzed against Milli-Q water for $72 \mathrm{~h}$ recharging the system with fresh water every $8 \mathrm{~h}$. The NPs solution was collected and the solvent was removed under reduced pressure working at a temperature lower than $45^{\circ} \mathrm{C}$. To completely remove unbound ligands, NPs were washed several times with hot ethanol. The final ratio MDDS:F6 was 1.5:1. Solubility properties: Good solubility in water; not soluble in ethanol, methanol, and acetone. UV-vis (water) $\lambda_{\max }(\mathrm{nm})$ : Weak surface plasmon band at $510 \mathrm{~nm} .{ }^{1} \mathrm{H}$ NMR $\left(500 \mathrm{MHz}, \mathrm{D}_{2} \mathrm{O}\right): \delta=0.9-1.60\left(\mathrm{br}, \mathrm{CH}_{2}\right), 1.77(\mathrm{br}$, $\mathrm{CH}_{2} \mathrm{CH}_{2} \mathrm{SH}$ and $\mathrm{CH}_{2} \mathrm{CH}_{2} \mathrm{SO}_{3} \mathrm{Na}$ ), 2.88 (br, $\mathrm{CH}_{2} \mathrm{SO}_{3} \mathrm{Na}$ ). TEM: $X_{\mathrm{m}}=3.4 \mathrm{~nm} ; \sigma=0.7 \mathrm{~nm} ; n=209$. TG Analysis: $16 \%$. Average composition: $\mathrm{Au}_{1415}(\mathrm{MDDS})_{129}(\mathrm{~F} 6)_{87}$.

Synthesis of NP-MDA/F6-a. A $250 \mathrm{~mL}$ round-bottom flask was charged with $80 \mathrm{mg}\left(0.20 \times 10^{-3} \mathrm{~mol}, 1\right.$ equiv $)$ of $\mathrm{HAuCl}_{4}$. $3 \mathrm{H}_{2} \mathrm{O}$ dissolved in $44 \mathrm{~mL}$ of deoxygenated ethanol and $0.14 \times$ $10^{-3}$ mol ( 0.66 equiv) of the thiol mixture (HF6:HMDA = $0.65: 1)$. Then, a $0.11 \mathrm{M}$ solution of $\mathrm{NaBH}_{4}$ in deoxygenated ethanol $\left(2.3 \times 10^{-3} \mathrm{~mol}, 11.3\right.$ equiv $)$ was added dropwise over $15 \mathrm{~min}$. The mixture was stirred for $3 \mathrm{~h}$ and the reaction vessel was then kept at $4{ }^{\circ} \mathrm{C}$ overnight; the precipitated NPs were collected and the solvent was discarded. The precipitated NPs were washed with ethanol and acetone and dried under vacuum. The NPs were dialyzed against Milli-Q water for $72 \mathrm{~h}$ recharging the system with fresh water ca. every $8 \mathrm{~h}$. The NP solution was collected and the solvent was removed under vacuum working at temperature below $45{ }^{\circ} \mathrm{C}$. The NPs were further purified by size exclusion chromatography on Sephadex LH-20 using methanol as eluent. The final ratio MDA:F6 was 5:1. Solubility properties: Good solubility in ethanol, methanol, and acetone. UV-vis (water) $\lambda_{\max }(\mathrm{nm})$ : Weak surface plasmon band at $500 \mathrm{~nm} .{ }^{1} \mathrm{H}$ NMR $\left(500 \mathrm{MHz}, \mathrm{D}_{2} \mathrm{O}\right): \delta=1.10-1.50$ (br, $\mathrm{CH}_{2}$ ), 1.60 (br, $\mathrm{CH}_{2} \mathrm{CH}_{2} \mathrm{SH}$ and $\mathrm{CH}_{2} \mathrm{CH}_{2} \mathrm{COOH}$ ), 2.85 (br, $\underline{\mathrm{CH}}_{2} \mathrm{COOH}$ ) ppm. TEM: $X_{\mathrm{m}}=3.01 \mathrm{~nm} ; \sigma=0.52 \mathrm{~nm} ; n=$ 234. TG Analysis: 20\%. Average composition: $\mathrm{Au}_{976}(\mathrm{MDA})_{136}(\mathrm{~F} 6)_{28}$.

Synthesis of NP-MDA/F6-b. A $250 \mathrm{~mL}$ round-bottom flask was charged with $99.3 \mathrm{mg}\left(0.25 \times 10^{-3} \mathrm{~mol}, 1\right.$ equiv $)$ of $\mathrm{HAuCl}_{4} \cdot 3 \mathrm{H}_{2} \mathrm{O}$ dissolved in $56 \mathrm{~mL}$ of deoxygenated ethanol and $0.17 \times 10^{-3} \mathrm{~mol}(0.67$ equiv) of the thiols mixture (HF6:HMDA $=0.76: 1)$. Then, a $0.11 \mathrm{M}$ solution of $\mathrm{NaBH}_{4}$ in deoxygenated ethanol $\left(2.83 \times 10^{-3} \mathrm{~mol}, 11.3\right.$ equiv $)$ was added dropwise over $15 \mathrm{~min}$. The mixture was stirred for $3 \mathrm{~h}$ and the reaction vessel was then kept at $4{ }^{\circ} \mathrm{C}$ overnight; the precipitated NP were collected and the solvent was discarded. The precipitated NPs were washed with ethanol $(3 \times 20 \mathrm{~mL})$, acetone $(3 \times 20 \mathrm{~mL})$, and DCM $(3 \times 20 \mathrm{~mL})$ and dried under vacuum obtaining $43.4 \mathrm{mg}$ of NPs. The final ratio MDA:F6 was 2.9:1. Solubility properties: Low solubility in ethanol and acetone; good solubility in methanol. UV-vis (methanol) $\lambda_{\max }$ $(\mathrm{nm})$ : Weak surface plasmon band at $523 \mathrm{~nm} .{ }^{1} \mathrm{H}$ NMR (500 $\left.\mathrm{MHz}, \mathrm{CD}_{3} \mathrm{OD}\right): \delta=1.10-1.50$ (br, $\left.\mathrm{CH}_{2}\right), 1.60$ (br, $\mathrm{C}_{2} \mathrm{CH}_{2} \mathrm{SH}$ and $\left.\mathrm{CH}_{2} \mathrm{CH}_{2} \mathrm{COOH}\right), 2.19$ (br, $\left.\underline{\mathrm{C}}_{2} \mathrm{COOH}\right)$ ppm. TEM: $X_{\mathrm{m}}=2.45 \mathrm{~nm} ; \sigma=0.56 \mathrm{~nm} ; n=488$. TG Analysis: $33 \%$. Average composition: $\mathrm{Au}_{523}(\mathrm{MDA})_{90}(\mathrm{~F} 6)_{30}$.

Synthesis of NP-MDA/F6-C. A three-neck round-bottom flask was charged with $81.8 \mathrm{mg}\left(2.08 \times 10^{-4} \mathrm{~mol}, 1\right.$ equiv $)$ of $\mathrm{HAuCl}_{4} \cdot 3 \mathrm{H}_{2} \mathrm{O}$ dissolved in $45 \mathrm{~mL}$ of deoxygenated ethanol and $1.38 \times 10^{-4} \mathrm{~mol}(0.66$ equiv) of the thiol mixture $($ HF6:HMDA $=1.3: 1)$. Then, a $0.11 \mathrm{M}$ solution of $\mathrm{NaBH}_{4}$ in deoxygenated ethanol $\left(2.35 \times 10^{-3} \mathrm{~mol}, 11.3\right.$ equiv $)$ was added dropwise over $11 \mathrm{~min}$. The mixture was stirred at room temperature for $3 \mathrm{~h}$ and then the NPs were precipitated by addition of hexane. The precipitate was repeatedly washed with hexane and the crude material was further purified by gel permeation chromatography on Sephadex LH-20 using methanol as eluent. The purified NPs were obtained as a brown-red solid. The final ratio MDA:F6 was 1.5:1. Solubility properties: Good solubility in ethanol, methanol, and acetone. UV-vis (water) $\lambda_{\max }(\mathrm{nm})$ : Weak surface plasmon band at 508 nm. ${ }^{1} \mathrm{H}$ NMR (500 MHz, $\left.\mathrm{CD}_{3} \mathrm{OD}\right): \delta=0.9-1.50\left(\mathrm{br}, \mathrm{CH}_{2}\right)$, 1.60 (br, $\mathrm{CH}_{2} \mathrm{CH}_{2} \mathrm{SH}$ and $\mathrm{CH}_{2} \mathrm{CH}_{2} \mathrm{COOH}$ ), 2.25 (br, $\mathrm{C}_{2} \mathrm{COOH}$ ). TEM: $X_{\mathrm{m}}=2.5 \mathrm{~nm} ; \sigma=0.3 \mathrm{~nm} ; n=204$. Average composition: $\mathrm{Au}_{523}(\mathrm{MDA})_{72}(\mathrm{~F} 6)_{49}$.

Synthesis of NP-TMDA/F6-a. A $250 \mathrm{~mL}$ three-neck round-bottom flask was charged with $80 \mathrm{mg}\left(2.03 \times 10^{-4}\right.$ mol, 1 equiv) of $\mathrm{HAuCl}_{4} \cdot 3 \mathrm{H}_{2} \mathrm{O}$ dissolved in $44 \mathrm{~mL}$ of deoxygenated ethanol and $1.35 \times 10^{-4} \mathrm{~mol}(0.66$ equiv) of the thiol mixture (HF6:HTMDA = 0.65:1). Then, a $0.11 \mathrm{M}$ solution of $\mathrm{NaBH}_{4}$ in deoxygenated ethanol $\left(2.3 \times 10^{-3} \mathrm{~mol}\right.$, 11.3 equiv) was added dropwise over $15 \mathrm{~min}$. The solution becomes brown, observing some precipitation of the NPs. The mixture was stirred for $3 \mathrm{~h}$ and the reaction vessel was then kept at $4{ }^{\circ} \mathrm{C}$ overnight; the precipitated NPs were collected and the solvent was discarded. The crude material was repeatedly washed with DCM to remove unbound ligands. The final ratio 
TMDA:F6 is 5:1. Solubility properties: soluble in methanol, ethanol; low solubility in water. UV-vis (water) $\lambda_{\max }(\mathrm{nm})$ : surface plasmon band at $525 \mathrm{~nm} .{ }^{1} \mathrm{H}$ NMR $(500 \mathrm{MHz}$, $\left.\mathrm{CD}_{3} \mathrm{OD}\right): \delta=3.33\left(\mathrm{br}, \mathrm{CH}_{2} \mathrm{~N}\left(\mathrm{CH}_{3}\right)_{3}\right), 3.17$ (br, $\left.\mathrm{N}\left(\mathrm{CH}_{3}\right)_{3}\right)$, 1.78 (br, $\left.\mathrm{CH}_{2} \mathrm{CH}_{2} \mathrm{~N}\left(\mathrm{CH}_{3}\right)_{3}\right), 1.60-0.9\left(\mathrm{br}, \mathrm{CH}_{2}\right)$. TEM: $X_{\mathrm{m}}=$ $3.9 \mathrm{~nm} ; \sigma=0.9 \mathrm{~nm} ; n=583$. TG Analysis: $19 \%$. Average composition: $\mathrm{Au}_{2406}(\mathrm{TMDA})_{256}(\mathrm{~F} 6)_{51}$.

Synthesis of NP-TMDA/F6-b. A $250 \mathrm{~mL}$ three-neck round-bottom flask was charged with $101 \mathrm{mg}\left(0.25 \times 10^{-3}\right.$ mol, 1 equiv) of $\mathrm{HAuCl}_{4} \cdot 3 \mathrm{H}_{2} \mathrm{O}$ dissolved in $56 \mathrm{~mL}$ of deoxygenated ethanol and $0.169 \times 10^{-3} \mathrm{~mol}(0.68$ equiv) of the thiol mixture (HF6:HTMDA $=0.77: 1)$. Then, a $0.11 \mathrm{M}$ solution of $\mathrm{NaBH}_{4}$ in deoxygenated ethanol $\left(2.88 \times 10^{-3} \mathrm{~mol}\right.$, 11.3 equiv) was added dropwise over $20 \mathrm{~min}$. The solution became brown, observing some precipitation of the NPs; the mixture was stirred for 3 . The precipitated NPs were collected and the solvent discarded. The crude material was washes with acetone $(3 \times 20 \mathrm{~mL}), \mathrm{DCM}(3 \times 20 \mathrm{~mL})$, and acetone $(6 \times 20$ $\mathrm{mL})$; the crude material was dissolved in a few milliliters of methanol and the NPs were precipitated by adding hexane. The precipitate was washed with DCM $(2 \times 20 \mathrm{~mL})$, acetone $(2 \times$ $20 \mathrm{~mL})$, and DCM $(2 \times 5 \mathrm{~mL})$ and dried obtaining $53.5 \mathrm{mg}$ of clean NPs as a reddish solid. The final ratio TMDA:F6 was 1.1:1. Solubility properties: soluble in methanol, ethanol; low solubility in water. UV-vis (water) $\lambda_{\max }(\mathrm{nm})$ : surface plasmon band at $\left.521 \mathrm{~nm} .{ }^{1} \mathrm{H} \mathrm{NMR} \mathrm{(500} \mathrm{MHz,} \mathrm{CD} \mathrm{OD}\right): \delta=3.33(\mathrm{br}$, $\left.\mathrm{CH}_{2} \mathrm{~N}\left(\mathrm{CH}_{3}\right)_{3}\right), 3.17$ (br, $\left.\mathrm{N}\left(\mathrm{CH}_{3}\right)_{3}\right), 1.78$ (br, $\mathrm{CH}_{2} \mathrm{CH}_{2} \mathrm{~N}$ $\left.\left(\mathrm{CH}_{3}\right)_{3}\right), 1.60-0.9$ (br, $\left.\mathrm{CH}_{2}\right)$. TEM: $X_{\mathrm{m}}=4.16 \mathrm{~nm} ; \sigma=0.7$ $\mathrm{nm} ; n=339$. TG Analysis: $15 \%$. Average composition: $\mathrm{Au}_{2406}(\mathrm{TMDA})_{131}(\mathrm{~F} 6)_{119}$.

Synthesis of NP-TMDA/F6-C. A $250 \mathrm{~mL}$ three-neck roundbottom flask was charged with $98 \mathrm{mg}\left(0.249 \times 10^{-3} \mathrm{~mol}, 1\right.$ equiv) of $\mathrm{HAuCl}_{4} \cdot 3 \mathrm{H}_{2} \mathrm{O}$ dissolved in $54 \mathrm{~mL}$ of deoxygenated ethanol and $0.166 \times 10^{-3} \mathrm{~mol}(0.66$ equiv) of the thiol mixture (HF6:HTMDA = 1.3:1). Then, a $0.11 \mathrm{M}$ solution of $\mathrm{NaBH}_{4}$ in deoxygenated ethanol $\left(2.82 \times 10^{-3} \mathrm{~mol}, 11.3\right.$ equiv $)$ was added dropwise over $15 \mathrm{~min}$. The solution became brown, observing some precipitation of the NPs; the mixture was stirred for $3 \mathrm{~h}$ and afterward the reaction vessel was placed at $4{ }^{\circ} \mathrm{C}$ overnight. The precipitated NPs were collected and the solvent discarded. The crude material was washed with DCM obtaining $46 \mathrm{mg}$ of clean NPs as a reddish solid. The final ratio TMDA:F6 was 1.3:1. Solubility properties: Soluble in methanol, ethanol; low solubility in water. UV-vis (water) $\lambda_{\max }(\mathrm{nm})$ : surface plasmon band at $525 \mathrm{~nm} .{ }^{1} \mathrm{H}$ NMR (500 MHz, $\left.\mathrm{CD}_{3} \mathrm{OD}\right): \delta=3.33(\mathrm{br}$, $\left.\mathrm{CH}_{2} \mathrm{~N}\left(\mathrm{CH}_{3}\right)_{3}\right), 3.17$ (br, $\left.\mathrm{N}\left(\mathrm{CH}_{3}\right)_{3}\right), 1.78$ (br, $\mathrm{CH}_{2} \mathrm{CH}_{2} \mathrm{~N}$ $\left.\left(\mathrm{CH}_{3}\right)_{3}\right), 1.60-0.9\left(\mathrm{br}, \mathrm{CH}_{2}\right)$. TEM: $X_{\mathrm{m}}=4.0 \mathrm{~nm} ; \sigma=0.9 \mathrm{~nm}$; $n=362$. TG Analysis: 16\%. Average composition: $\mathrm{Au}_{2406}(\mathrm{TMDA})_{160}(\mathrm{~F} 6)_{124}$.

Preparation of NP-MDDS/F6/Bodipy. In a $25 \mathrm{~mL}$ roundbottom flask $11.4 \mathrm{mg}$ of NP-MDDS/F6-b was dissolved by using $5 \mathrm{~mL}$ of deoxygenated $\mathrm{mQ}$ water under an argon atmosphere, and $150 \mu \mathrm{L}$ of a $1.94 \mathrm{mM}$ solution of HBodipy in $\mathrm{DMF} / \mathrm{H}_{2} \mathrm{O} 4 / 1$ was added; the mixture was kept under stirring at $25{ }^{\circ} \mathrm{C}$ for 4 days. To completely remove unbound ligands, particles were dissolved in Milli-Q water and dialyzed against millQ water for a total time of $72 \mathrm{~h}$. The system was recharged with fresh water every $8 \mathrm{~h}$. The NPs solution was collected from the dialysis tube and used as such.

Preparation of NP-TMDA/F6/Bodipy. In a $25 \mathrm{~mL}$ roundbottom flask $10 \mathrm{mg}$ of NP-TMDA/F6-c was dissolved by using $5 \mathrm{~mL}$ of deoxygenated $\mathrm{mQ}$ water under an argon atmosphere, and $150 \mu \mathrm{L}$ of a $1.94 \mathrm{mM}$ solution of HBodipy in $\mathrm{DMF} / \mathrm{H}_{2} \mathrm{O}$
$4 / 1$ were added; the mixture was kept under stirring at $25{ }^{\circ} \mathrm{C}$ for 4 days. The NPs were purified by dialysis against $1 \mathrm{~L}$ of Milli-Q for a total time of $72 \mathrm{~h}$ recharging the system with fresh water every $8 \mathrm{~h}$. The NPs solution was used as such.

Preparation of NPs-C8TEG/Bodipy. In a $25 \mathrm{~mL}$ roundbottom flask $10 \mathrm{mg}$ of NP-C8TEG was dissolved using $5 \mathrm{~mL}$ of deoxygenated methanol under an argon atmosphere, and 150 $\mu \mathrm{L}$ of a $1.94 \mathrm{mM}$ solution of HBodipy in DMF/ $\mathrm{H}_{2} \mathrm{O} 4 / 1$ was added; the mixture was kept under stirring at $25^{\circ} \mathrm{C}$ for 4 days. The solvent was removed under reduced pressure at a temperature below $45{ }^{\circ} \mathrm{C}$. To completely remove unbound ligands, the NPs were purified by size exclusion chromatography by using Sephadex LH-20 and methanol as eluent.

Preparation of NP-F8PEG/Bodipy. In a $25 \mathrm{~mL}$ roundbottom flask $10 \mathrm{mg}$ of NPs-F8PEG was dissolved using $5 \mathrm{~mL}$ of deoxygenated methanol under an argon atmosphere, and 150 $\mu \mathrm{L}$ of a $1.94 \mathrm{mM}$ solution of HBodipy in DMF/ $\mathrm{H}_{2} \mathrm{O} 4 / 1$ was added; the mixture was kept under stirring at $25{ }^{\circ} \mathrm{C}$ for 4 days. The solvent was removed under reduced pressure at a temperature below $45{ }^{\circ} \mathrm{C}$. The NPs were purified by size exclusion chromatography by using Sephadex LH-20 and methanol as eluent.

Cell Culture and Fluorescence Imaging. Human cervical carcinoma cells $(\mathrm{HeLa})$ were grown in a standard culture media at $37{ }^{\circ} \mathrm{C}$ and in $95 \%$ air $/ 5 \% \mathrm{CO}_{2}$ atmosphere. Cells were seeded in a $\mu$-Slide 8 -well ibidi plate (Martinsried, Germany) at a density of $5 \times 10^{4}$ cells per well $\left(1.0 \mathrm{~cm}^{2}\right)$ and were allowed to adhere overnight. Before cell incubation with nanoparticles, the medium containing fetal bovine serum was replaced with serum-free medium to avoid unspecific binding of the NPs to serum proteins. Cells were then incubated with Bodipy labeled $\mathrm{NP}$ for $3.5 \mathrm{~h}$ at $37^{\circ} \mathrm{C}$. After incubation the cells were washed 3 times with PBS. Nuclei were counterstained with Hoechst 33342 (Invitrogen, Oregon, USA), according to the manufacturer's instructions. Cellular internalization of the fluorescently labeled NP was visualized with an inverted confocal laser scanning microscope (CLSM, Carl Zeiss LSM 510) equipped with a $63 \times / 1.3$ oil DIC objective, using excitation lines at 405 (Hoechst 33342) and $633 \mathrm{~nm}$ (Bodipy (650/665 nm)). ImageJ software was used for image analysis.

Cell Viability-FACS Analysis. HeLa cell incubation with Bodipy labeled NPs in a concentration range of $0.05-0.2 \mathrm{mg} /$ $\mathrm{mL}$ was performed as described above. After incubation, $5 \times$ $10^{5}$ cells were collected by trypsination and washed with PBS containing $1 \%$ BSA. The staining of nonviable cells was performed with Propidium Iodide $(50 \mu \mathrm{g} / \mathrm{mL}$ in PBS) for 5 min at room temperature. The samples were analyzed immediately on a flow cytometer (FACS Canto II, BD Biosciences) with excitation at $488 \mathrm{~nm}$ for PI and an excitation at $633 \mathrm{~nm}$ for Bodipy.

\section{ASSOCIATED CONTENT}

\section{Supporting Information}

The Supporting Information is available free of charge on the ACS Publications website at DOI: 10.1021/acs.bioconjchem.6b00585.

Synthetic and characterization details of the ligands HMDDS, HMDA, HTMDA, NP-MUS/F8, NP-MDDS/ F8, NP-C8TEG, NP-F8PEG. Characterization data for the nanoparticles NP-MDDS/F6, NP-MDA/F6, and NPTMDA/F6. Results of the red blood assay for the nanoparticle systems NP-MDDS/F6/Bodipy, NP- 
TMDA/F6/Bodipy, NP-C8TEG/Bodipy, and NPF8PEG/Bodipy. FACS analysis of HeLa cells incubated with $0.2 \mathrm{~mL} / \mathrm{mL}$ of the nanoparticle systems. (PDF)

\section{AUTHOR INFORMATION}

\section{Corresponding Authors}

*E-mail: ppengo@units.it.

*E-mail: lpasquato@units.it.

\section{ORCID ${ }^{\odot}$}

Patrizia Canton: 0000-0003-1604-5265

Barbara Sanavio: 0000-0001-5837-4097

Francesco Stellacci: 0000-0003-4635-6080

Lucia Pasquato: 0000-0003-1842-9609

Notes

The authors declare no competing financial interest.

\section{ACKNOWLEDGMENTS}

This work was financially supported by the Italian Ministry of Health, project GR-2009-1579849 and the University of Trieste (FRA Projects 2014, 2015).

\section{REFERENCES}

(1) Nishio, T., Niikura, K., Matsuo, Y., and Ijiro, K. (2010) SelfLubricating Nanoparticles: Self-Organization into 3D-Superlattices During a fast Drying Process. Chem. Commun. 46, 8977-8979.

(2) Niikura, K., Iyo, N., Higuchi, T., Nishio, T., Jinnai, H., Fujitani, N., and Ijiro, K. (2012) Gold Nanoparticles Coated with SemiFluorinated Oligo(ethylene glycol) Produce Sub-100 nm Nanoparticle Vesicles without Templates. J. Am. Chem. Soc. 134, 7632-7635.

(3) Niikura, K., Iyo, N., Matsuo, Y., Mitomo, H., and Ijiro, K. (2013) Sub-100 nm Gold Nanoparticle Vesicles as a Drug Delivery Carrier enabling Rapid Drug Release upon Light Irradiation. ACS Appl. Mater. Interfaces 5, 3900-3907.

(4) Ding, Y., Jiang, Z., Saha, K., Kim, C.-S., Kim, S.-T., Landis, R. F., and Rotello, V. M. (2014) Gold Nanoparticles for Nucleic Acid Delivery. Mol. Ther. 22, 1075-1083.

(5) Ghosh, P., Han, G., De, M., Kim, C. K., and Rotello, V. M. (2008) Gold Nanoparticles in Delivery Applications. Adv. Drug Delivery Rev. 60, 1307-1315.

(6) Ellipilli, S., Murthy, R. V., and Ganesh, K. N. (2016) Perfluoroalkylchain Conjugation as a new Tactic for Enhancing Cell Permeability of Peptide Nucleic Acids (PNAs) via Reducing the Nanoparticle Size. Chem. Commun. 52, 521-524.

(7) Rocha, S., Thünemann, A. F., Carmo Pereira, M., Coelho, M. A. N., Möhwald, H., and Brezesinski, G. (2005) The Conformation of B18 Peptide in the Presence of Fluorinated and Alkylated Nanoparticles. ChemBioChem 6, 280-283.

(8) Rocha, S., Thünemann, A. F., do Carmo Pereira, M., Coelho, M., Möhwald, H., and Brezesinski, G. (2008) Influence of Fluorinated and Hydrogenated Nanoparticles on the Structure and Fibrillogenesis of Amyloid Beta-Peptide. Biophys. Chem. 137, 35-42.

(9) Boccalon, M., Bidoggia, S., Romano, F., Gualandi, F., Franchi, P., Lucarini, M., Pengo, P., and Pasquato, L. (2015) Gold Nanoparticles as Drug Carriers: a Contribution to the Quest for Basic Principles for Monolayer Design. J. Mater. Chem. B 3, 432-439.

(10) Ma, S., Zhou, J., Wali, A. R. M., He, Y., Xu, X., Tang, J. Z., and $\mathrm{Gu}, \mathrm{Z}$. (2015) Self-assembly of $\mathrm{pH}$-Sensitive Fluorinated Peptide Dendron Functionalized Dextran Nanoparticles for On-Demand Intracellular Drug Delivery. J. Mater. Sci.: Mater. Med. 26, 219.

(11) Porsch, C., Zhang, Y., Östlund, Å., Damberg, P., Ducani, C., Malmström, E., and Nyström, A. M. (2013) In Vitro Evaluation of Non-Protein Adsorbing Breast Cancer Theranostics Based on ${ }^{19} \mathrm{~F}$ Polymer Containing Nanoparticles. Part. Part. Syst. Charact. 30, 381390.
(12) Janjic, J. M., Srinivas, M., Kadayakkara, D. K. K., and Ahrens, E. T. (2008) Self-delivering Nanoemulsions for Dual Fluorine-19 MRI and Fluorescence Detection. J. Am. Chem. Soc. 130, 2832-2841.

(13) Boccalon, M., Franchi, P., Lucarini, M., Delgado, J. J., Sousa, F., Stellacci, F., Zucca, I., Scotti, A., Spreafico, R., Pengo, P., et al. (2013) Gold Nanoparticles Protected by Fluorinated Ligands for ${ }^{19} \mathrm{~F}$ MRI. Chem. Commun. 49, 8794-8796.

(14) Posocco, P., Gentilini, C., Bidoggia, S., Pace, A., Franchi, P., Lucarini, M., Fermeglia, M., Pricl, S., and Pasquato, L. (2012) SelfOrganization of Mixtures of Fluorocarbon and Hydrocarbon Amphiphilic Thiolates on the Surface of Gold Nanoparticles. ACS Nano 6, 7243-7253.

(15) Şologan, M., Marson, D., Polizzi, S., Pengo, P., Boccardo, S., Pricl, S., Posocco, P., and Pasquato, L. (2016) Patchy and Janus Nanoparticles by Self-Organization of Mixtures of Fluorinated and Hydrogenated Alkanethiolates on the Surface of a Gold Core. ACS Nano 10, 9316-9325.

(16) Gentilini, C., Franchi, P., Mileo, E., Polizzi, S., Lucarini, M., and Pasquato, L. (2009) Formation of Patches on 3D SAMs Driven by Thiols with Immiscible Chains Observed by ESR Spectroscopy. Angew. Chem., Int. Ed. 48, 3060-3064.

(17) Elbert, R., Folda, T., and Ringsdorf, H. (1984) Saturated and Polymerizable Amphiphiles with Fluorocarbon Chains. Investigation in Monolayers and Liposomes. J. Am. Chem. Soc. 106, 7687-7692.

(18) Yoder, N. C., Kalsani, V., Schuy, S., Vogel, R., Janshoff, A., and Kumar, K. (2007) Nanoscale Patterning in Mixed FluorocarbonHydrocarbon Phospholipid Bilayers. J. Am. Chem. Soc. 129, 90379043.

(19) Overney, R. M., Meyer, E., Frommer, J., Brodbeck, D., Luthi, R., Howald, L., Guntherodt, H.-J., Fujihira, M., Takano, H., and Gotoh, Y. (1992) Friction measurements on phase-separated thin films with a modified atomic force microscope. Nature 359, 133-135.

(20) Schönherr, H., and Ringsdorf, H. (1996) Self-Assembled Monolayers of Symmetrical and Mixed Alkyl Fluoroalkyl Disulfides on Gold. 1. Synthesis of Disulfides and Investigation of Monolayer Properties. Langmuir 12, 3891-3897.

(21) Jaschke, M., Schönherr, H., Wolf, H., Butt, H.-J., Bamberg, E., Besocke, M. K., and Ringsdorf, H. (1996) Structure of Alkyl and Perfluoroalkyl Disulfide and Azobenzenethiol Monolayers on Gold(111) Revealed by Atomic Force Microscopy. J. Phys. Chem. 100, 2290-2301.

(22) Schönherr, H., Ringsdorf, H., Jaschke, M., Butt, H.-J., Bamberg, E., Allinson, H., and Evans, S. D. (1996) Self-Assembled Monolayers of Symmetrical and Mixed Alkyl Fluoroalkyl Disulfides on Gold. 2. Investigation of Thermal Stability and Phase Separation. Langmuir 12, 3898-3904.

(23) Tsao, M.-W., Rabolt, J. F., Schönherr, H., and Castner, D. G. (2000) Semifluorinated/Hydrogenated Alkylthiol Thin Films: A Comparison between Disulfides and Thiol Binary Mixtures. Langmuir $16,1734-1743$

(24) Jackson, A. M., Myerson, J. W., and Stellacci, F. (2004) Spontaneous Assembly of Subnanometre-Ordered Domains in the Ligand Shell of Monolayer-Protected Nanoparticles. Nat. Mater. 3, 330-336.

(25) Jackson, A. M., Hu, Y., Silva, P. J., and Stellacci, F. (2006) From Homoligand- to Mixed-Ligand- Monolayer-Protected Metal Nanoparticles: A Scanning Tunneling Microscopy Investigation. J. Am. Chem. Soc. 128, 11135-11149.

(26) Singh, C., Ghorai, P. K., Horsch, M. A., Jackson, A. M., Larson, R. G., Stellacci, F., and Glotzer, S. C. (2007) Entropy-Mediated Patterning of Surfactant-Coated Nanoparticles and Surfaces. Phys. Rev. Lett. 99, 226106.

(27) Ghorai, P. K., and Glotzer, S. C. (2010) Atomistic Simulation Study of Striped Phase Separation in Mixed-Ligand Self-Assembled Monolayer Coated Nanoparticles. J. Phys. Chem. C 114, 19182-19187.

(28) Pillai, P. P., Huda, S., Kowalczyk, B., and Grzybowski, B. A. (2013) Controlled pH Stability and Adjustable Cellular Uptake of Mixed-Charge Nanoparticles. J. Am. Chem. Soc. 135, 6392-6395. 
(29) Hühn, D., Kantner, K., Geidel, C., Brandholt, S., De Cock, I., Soenen, S. J. H., Rivera-Gil, P., Montenegro, J.-M., Braeckmans, K., Müllen, K., et al. (2013) Polymer-Coated Nanoparticles Interacting with Proteins and Cells: Focusing on the Sign of the Net Charge. ACS Nano 7, 3253-3263.

(30) Mout, R., Moyano, D. F., Rana, S., and Rotello, V. M. (2012) Surface Functionalization of Nanoparticles for Nanomedicine. Chem. Soc. Rev. 41, 2539-2544.

(31) Kobayashi, K., Niikura, K., Takeuchi, C., Sekiguchi, S., Ninomiya, T., Hagiwara, K., Mitomo, H., Ito, Y., Osada, Y., and Ijiro, K. (2014) Enhanced Cellular Uptake of Amphiphilic Gold Nanoparticles with Ester Functionality. Chem. Commun. 50, 12651267.

(32) Verma, A., Uzun, O., Hu, Y., Hu, Y., Han, H.-S., Watson, N., Chen, S., Irvine, D. J., and Stellacci, F. (2008) Surface-StructureRegulated Cell-Membrane Penetration by Monolayer-Protected Nanoparticles. Nat. Mater. 7, 588-595.

(33) van Lehn, R. C., Atukorale, P. U., Carney, R. P., Yang, Y.-S., Stellacci, F., Irvine, D. J., and Alexander-Katz, A. (2013) Effect of Particle Diameter and Surface Composition on the Spontaneous Fusion of Monolayer-Protected Gold Nanoparticles with Lipid Bilayers. Nano Lett. 13, 4060-4067.

(34) van Lehn, R. C., and Alexander-Katz, A. (2014) Free energy Change for Insertion of Charged, Monolayer-Protected Nanoparticles into Lipid Bilayers. Soft Matter 10, 648-658.

(35) Sabella, S., Carney, R. P., Brunetti, V., Malvindi, M. A., Al-Juffali, N., Vecchio, G., Janes, S. M., Bakr, O. M., Cingolani, R., Stellacci, F., et al. (2014) A General Mechanism for Intracellular Toxicity of MetalContaining Nanoparticles. Nanoscale 6, 7052-7061.

(36) Uzun, O., Hu, Y., Verma, A., Chen, S., Centrone, A., and Stellacci, F. (2008) Water-Soluble Amphiphilic Gold Nanoparticles with Structured Ligand Shells. Chem. Commun., 196-198.

(37) In the nanoparticle designation F8 stands for the thiolate derived from thiol HF8 and MUS stands for the thiolate derived from thiol HMUS; all of the nanoparticles in the text are named accordingly.

(38) Şologan, M., Cantarutti, C., Bidoggia, S., Polizzi, S., Pengo, P., and Pasquato, L. (2016) Routes to the Preparation of Mixed Monolayers of Fluorinated and Hydrogenated Alkanethiolates Grafted on the Surface of Gold Nanoparticles. Faraday Discuss. 191, 527-543.

(39) Stewart, A., Zheng, S., McCourt, M. R., and Bell, S. E. J. (2012) Controlling Assembly of Mixed Thiol Monolayers on Silver Nanoparticles to Tune Their Surface Properties. ACS Nano 6, 3718-3726.

(40) Gentilini, C., Evangelista, F., Rudolf, P., Franchi, P., Lucarini, M., and Pasquato, L. (2008) Water-Soluble Gold Nanoparticles Protected by Fluorinated Amphiphilic Thiolates. J. Am. Chem. Soc. 130, 1567815682.

(41) Pengo, P., Polizzi, S., Battagliarin, M., Pasquato, L., and Scrimin, P. (2003) Synthesis, Characterization and Properties of Water-Soluble Gold Nanoparticles with Tunable Core Size. J. Mater. Chem. 13, 2471-2478.

(42) Andreozzi, P., Martinelli, C., Carney, R. P., Carney, T. M., and Stellacci, F. (2013) Erythrocyte Incubation as a Method for Free-Dye Presence Determination in Fluorescently Labeled Nanoparticles. Mol. Pharmaceutics 10, 875-882.

(43) Arvizo, R. R., Miranda, O. R., Thompson, M. A., Pabelick, C. M., Bhattacharya, R., Robertson, J. D., Rotello, V. M., Prakash, Y. S., and Mukherjee, P. (2010) Effect of Nanoparticle Surface Charge at the Plasma Membrane and Beyond. Nano Lett. 10, 2543-2548.

(44) Nativo, P., Prior, I. A., and Brust, M. (2008) Uptake and Intracellular Fate of Surface-Modified Gold Nanoparticles. ACS Nano 2, 1639-1644.

(45) Lin, J., and Alexander-Katz, A. (2013) Cell Membranes Open "Doors" for Cationic Nanoparticles/Biomolecules: Insights into Uptake Kinetics. ACS Nano 7, 10799-10808.

(46) Heikkila, E., Martinez-Seara, H., Gurtovenko, A. A., Javanainen, M., Häkkinen, H., Vattulainen, I., and Akola, J. (2014) Cationic Au Nanoparticle Binding with Plasma Membrane-like Lipid Bilayers: Potential Mechanism for Spontaneous Permeation to Cells Revealed by Atomistic Simulations. J. Phys. Chem. C 118, 11131-11141.
(47) Goodman, C. M., McCusker, C. D., Yilmaz, T., and Rotello, V. M. (2004) Toxicity of Gold Nanoparticles Functionalized with Cationic and Anionic Side Chains. Bioconjugate Chem. 15, 897-900. 